\title{
USE OF MEDICINAL PLANTS BY LIVESTOCK FARMERS IN A LOCAL MUNICIPALITY IN VHEMBE DISTRICT, SOUTH AFRICA
}

\author{
ChITURA, T. ${ }^{{ }^{*}}-$ Muvhali, P. T. ${ }^{1}-$ ShAI, K. ${ }^{1}-$ MushongA, B. ${ }^{2}-$ KANDIWA, E. $^{2}$ \\ ${ }^{I}$ Department of Agricultural Economics and Animal Production, University of Limpopo \\ Private Bag X1106, Sovenga 0727, South Africa \\ ${ }^{2}$ Department of Biomedical Sciences, School of Veterinary Medicine, Faculty of Agriculture and \\ Natural Resources, University of Namibia \\ Private bag X 13301, Mandume Ndemufayo Avenue, Pioneers Park, Windhoek, Namibia \\ *Corresponding author \\ e-mail:teedzai.chitura@ul.ac.za \\ (Received $27^{\text {th }}$ Jun 2018; accepted $14^{\text {th }}$ Aug 2018)
}

\begin{abstract}
Respondents $(n=180)$ from Mutale municipality, Limpopo Province, South Africa, were interviewed so as to assess the factors affecting the use of medicinal herbs in treatment of livestock diseases. A significantly greater proportion of males $(79.8 \%)$ than females $(52.7 \%)$ preferred a combination of treatment methods $(\mathrm{P}<0.05)$. A significantly greater proportion of females $(36.8 \%)$ than males $(10.6 \%)$ preferred using medicinal herbs only $(\mathrm{P}<0.05)$. There was no significant difference in the proportions of males and females using conventional drugs only $(\mathrm{P}>0.05)$. Overall, a significantly greater proportion of respondents between 20-40years old $(83.1 \%)$ preferred to use a combination of treatment methods $(\mathrm{P}<0.05)$. A significantly greater proportion of the unschooled respondents $(46.6 \%)$ preferred to use medicinal herbs only $(\mathrm{P}<0.05)$. A significantly greater proportion of the tertiary-schooled respondents $(50 \%)$, however, preferred to use conventional drugs only $(\mathrm{P}<0.05)$. Parts from Cassia abbreviata and Cissus quadrangularis were the preferred oral treatments for retained placenta, Pterocarpus angolensis and Combretum collinum were the preferred oral treatments for constipation in cattle. Cissus quadrangularis, Dichrostachys cinerea and Ximenia americana were preferred for topical treatment of wounds, Synadenium cupulare for arthritis, Ziziphus mucronata for mastitis, Maytanus eduncularis for fractures and Gossypium herbaceum for blindness in cattle, sheep and goats.
\end{abstract}

Keywords: herbal, ethno-veterinary, practices, Cassia abbreviata, South Africa

\section{Introduction}

Mutale is a rural Municipality in the Vhembe District of the Limpopo Province of South Africa. The municipality, like other places in Limpopo Province, is affected by climate change and receives minimal rainfall. Its poor human population depends mostly on livestock production. Viability of livestock production in Mutale is under threat of diseases which appear to be on the increase, in recent times, due to climate change. However, farmers cannot afford to buy modern drugs for treatment of livestock diseases. To keep their animals alive and healthy, farmers have resorted to the time-honoured approach of using plant remedies (ethno-veterinary or ethno-botanical) to treat the diseases affecting their animals.

The demographics of the farmers using ethno-veterinary medicine, their reasons for doing so, the species of plants used, the parts of plants used, and the specific diseases so treated, though documented elsewhere in South Africa and other developing countries, have, hitherto, not been documented in Mutale Municipality. The objective of this study was to document the demographics of farmers using plant and conventional drugs and the species of plants thus used in the treatment of common animal diseases in Mutale 
Municipality. The overarching aim of this study was to highlight the use of locally available natural resources (plant remedies) by resource constrained rural farmers as a sustainable way of combating climate change.

\section{Literature review}

Food security and opportunity for gainful employment has been a challenge with increasing population pressure the world over and is continually threatened by the effects of global warming. It is estimated that demand for animal products will be doubled by 2050. There is an urgent need for innovative sustainable production that also improves livelihood and food security (Notenbaert et al., 2017). Such production initiatives must harness knowledge from the informal sector that possibly helps protect the environment (Munda et al., 2016). Livestock production is one such solution to global food shortage contributing up to $80 \%$ of agricultural GDP in developing countries, including those in Africa. In addition, 600 million rural poor people rely on livestock for their livelihoods. Moreover, livestock and derived products act as a buffer against climatic unpredictability, greatly contributing to food security especially in periods of scarce agricultural resources. Livestock diseases and poor management practices are a major threat to sustainable livelihoods of resource-poor rural communities (Marandure et al., 2016). The livestock sector in Mutale local municipality sustains the livelihoods of the majority of inhabitants who are mainly small-scale livestock producers. In this area, the main vegetation type is the Mopane woodland, a type of savanna woodland ecosystem dominated by the tree Colophospermum mopane (also called mopane in local languages) (Makhado et al., 2012, 2014). Due to dry climate and poor soil conditions, land cultivation is difficult and livestock production is the only viable option to farmers and is thus their main and often sole means of survival and source of income. However, successful livestock production has been challenged by changing rural contexts such as limited or lack of grazing land (Doumbia et al., 2012), lack of medications (Usha et al., 2016), increased costs (Ritter et al., 2012) and drug resistance (Raot et al., 2016). In light of the foregoing, resourcelimited farmers resort to using locally available resources to control livestock diseases, ectoparasites and other related vectors (Mutibvu et al., 2012).

Over the years, rural farmers have used indigenous methods as an alternative solution for coping with disease constraints in both humans and animals (Ahmad et al., 2016; Paindla et al., 2013). These methods of treatment of animals using indigenous knowledge are broadly referred to as ethno-veterinary medicine (EVM) (Shen et al., 2010; Bartha et al., 2015; Usha et al., 2016; Caudell et al., 2017). The pharmacopeia usually used includes animal products, plant products as well as minerals for treating animals (Bartha et al., 2015; Raikwar and Maurya, 2015). According to Ahmad et al. (2016), the role of EVM in livestock production is beyond dispute. The knowledge is owned communally, under the custody of older members of the population depending on the community, ethnicity, sex, age and caste and is passed down through generations by oral tradition (Ahmad et al., 2016). It is clear from literature that EVM is usually practiced alongside or as an alternative to allopathic (modern western style) veterinary medicine (Shen et al., 2010; Claudell et al., 2017). It has been observed that, in nature, animals consume certain plants in order to derive treatment of various ailments afflicting them (Huffman, 2016). Raikwar and Maurya (2015) pointed out that availability and accessibility of such products at little or no cost are the major selling points for EVM to poor rural communities. In addition, EVM has gained popularity in recent times, in the face of an increasing demand for 
organically raised meat traceable to farms of origin; and the rise of a modern-day consumer willing to pay a higher premium for meat arising from organic farms that strictly adhere to animal welfare guidelines (Lans et al., 2012; Adedeji et al., 2013; Mayer et al., 2014).

There has been an interesting explosion of publications in the last decade from various sub regions of the world including North America (Lans et al., 2012), Australia (Vogl et al., 2016), China (Shen et al., 2010), Europe (Mayer, 2014; Bartha et al., 2015) the Indian subcontinent (Vijayagiri et al., 2012; Mamidala, 2013; Raikwar and Maurya, 2015; Ahmad et al., 2016; Usha et al., 2016) and Africa (McGaw and Eloff, 2008; Marandure, 2016; Caudell et al., 2017; Teklehaymanot, 2017) on EVM. Literature from India outnumbers that arising from any other part of the world, an indication of the strength of the link between India's tribal communities and nature (Paindla et al., 2009). The World Health Organization estimates that nearly $80 \%$ of the world's poor depend on EVM (Raikwar and Maurya, 2015). However, it is disappointing to note that, of the recent publications, only a few demonstrate the efficacy of EVM (Luseba et al., 2007; Ndhlala et al., 2009; Adamu et al., 2014; Sserunkuma et al., 2017). The majority of recent publications are EVM surveys documenting which diseases are treated by which plants (McGaw and Eloff, 2008; Shen et al., 2010; Lans et al., 2012; Vijayagiri et al., 2012; Mamidala, 2013; Mayer, 2014; Bartha et al., 2015; Raikwar and Maurya, 2015; Ahmad, et al., 2016; Marandure, 2016; Usha et al., 2016; Vogl et al., 2016; Caudell et al., 2017; Teklehaymanot, 2017) Studies in Africa and elsewhere indicated inadequate veterinary services and lack of low cost alternative technologies as impediments in overcoming livestock diseases (Getachew et al., 2015; Raikwar and Maurya, 2015; Shamim et al., 2015). There is a need to look for environment-friendly technologies in support of livestock welfare and health. Evidence gathered from previous research indicated that there is a scope for the use of EVM within the Southern African Sub region (Gabanakgosi et al., 2012; Maroyi, 2012; Chinsembu et al., 2014; Marandure, 2016) and particularly in South Africa (Luseba and Van der Merwe; 2006; McGaw et al., 2007; Moyo et al., 2009; Ndhlala et al., 2009; Maphosa, 2010; Moyo et al., 2013; Chauke et al., 2015; Tyasi and Nkohla, 2015). Documentation of ethno-veterinary practices is critically urgent so that the knowledge can be preserved, plants conserved and sustainably managed for the control of livestock diseases (Vijayagiri et al., 2012).

Some recent studies have shown that people living in the Venda area still hold a valuable knowledge on food and medicinal plants and that some of these plants can act as crucial factors in livelihood strategies of indigenous communities. Mopane woodlands are also believed to host a high diversity of plants with potential ethno-veterinary applications (Luseba and van der Merwe, 2006; Luseba and Tshisikhawe, 2013; Chinsembu et al., 2014). However, to date no systematic information has been gathered on plants locally used in maintaining livestock health and welfare in Mutale municipality. The aim of this study was to record and analyze traditional ethnobotanical knowledge concerning EVM and fodder plants in some communities living in Mopane woodlands surrounding the municipality of Mutale.

\section{Materials and methods}

The study was conducted in selected villages of Mutale local municipality, Vhembe district, Limpopo Province of the Republic of South Africa, over a period of three months (January-March 2014). Mutale local municipality is situated far north of the 
Limpopo Province largely inhabited by the Venda speaking people. The coordinates of the study area are $22^{\circ} 35^{\prime} 0$ " S, $30^{\circ} 40^{\prime} 0^{\prime \prime} \mathrm{E}$ (Fig. 1). The geographical outlook of the area is dominated by the Soutpansberg Mountains and sandy soils. The natural vegetation around the study area was identified as the savannah biome of the Mopane units (Colophospermum mopane) and central bushveld (Mucina and Rutherford, 2006). The area receives about $681 \mathrm{~mm}$ of rain per year with high rainfall of about $137 \mathrm{~mm}$ in summer and about $2 \mathrm{~mm}$ of rain experienced in winter (S. A. Explorer, 2014). The average midday temperature in the study area ranges from $29.2^{\circ} \mathrm{C}$ in summer to $22.1^{\circ} \mathrm{C}$ in winter. Small scale livestock production compliments crop production to provide food security and income for the households of the Mutale local municipality. Participation by the respondents in this study was voluntary and under no circumstances were the authors handling or applying any medication to animals during data collection of this study.

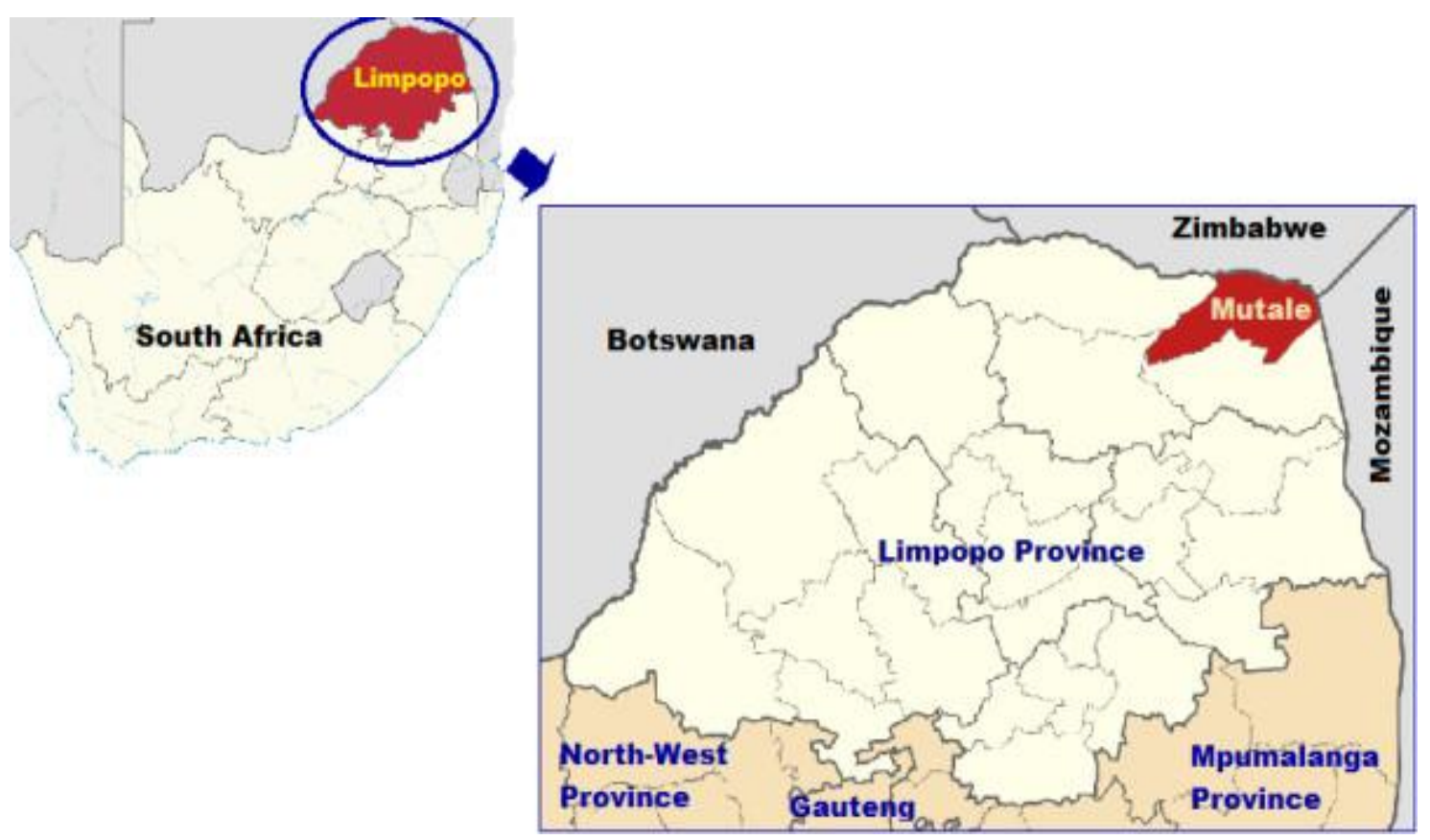

Figure 1. Map of Mutale local municipality, Vhembe District, South Africa

One hundred and eighty farmers (104 males and 76 females) were purposely selected and interviewed on their knowledge of livestock diseases and plants used for treatment of identified animal diseases. A structured questionnaire was used to gather information on the demographic characteristics (gender, age and level of education) of the respondents, livestock species kept and ability to identify common livestock diseases based on presenting symptoms. Additionally, the questionnaire captured data on the respondent's knowledge of the history of medicinal plants found in the study area. A majority of the respondents were not keen on stating their exact age thus leading to age being divided into three categories for this study; youth (less than 20 years old), medium aged (between 20 and 40 years old) and seniors (above 40 years of age). Identified plants were collected from their location during field trips within the study area and were further subjected to scientific identification at the University of Limpopo Larry Leach herbarium. Plant parts used, methods of preparation and the conditions for 
which the plants were used were recorded. For the interest of this study, a bark was referred to as the outermost layers of the stem in woody plants while layers covering the roots and branches were referred to as root bark and branches respectively. The data of this study was captured in Microsoft Excel 2013 and statistically analysed using the Statistical Package for Social Sciences (SPSS Inc. 2012). The Z test for comparison of proportions was also used to ascertain statistical significance and $\mathrm{p}<0.05$ was considered significant.

\section{Results}

The demographic distribution of the respondents is presented in Table 1. The majority of the respondents $(57.8 \%)$ were males. Almost half of the respondents $(49.4 \%)$ were in the $>40$ year old age category and the least $(17.8 \%)$ were in the <20year old category.

Table 1. Proportional distribution of respondents according to category

\begin{tabular}{c|c|c}
\hline Category & Number of respondents & Proportion (\%) \\
Gender & 104 & 57.8 \\
Male & 76 & 42.2 \\
Female & 32 & 17.8 \\
Age & 59 & 32.8 \\
<20years old & 89 & 49.4 \\
20-40years old & & \\
>40years old & 60 & 33.3 \\
Education & 29 & 16.1 \\
None & 63 & 35.0 \\
Primary & 28 & 15.6 \\
Secondary & & \\
Tertiary & 89 & 49.4 \\
Cattle & 52 & 28.9 \\
Poultry & 34 & 18.9 \\
Goats & 5 & 2.8 \\
Sheep & 18 & 10.0 \\
\hline Main livestock reared & 39 & 21.7 \\
Method of animal treatment & 123 & 68.3 \\
Conventional drugs only & 115 & 63.9 \\
Medicinal herbs only & 103 & 57.2 \\
Combination & 97 & 53.9 \\
Conditions frequently encountered & 84 & 46.7 \\
Retained placenta & 26.7 \\
Mastitis & 48 & 15.0 \\
Wounds & 27 & 10.6 \\
Unthriftiness & 19 & 3.3 \\
Fractures & 6 & 100 \\
Arthritis & &
\end{tabular}

A third of the respondents had no education and yet another third had secondary level education. Of the remaining third, almost equal proportions of respondents had primary $(16.1 \%)$ and tertiary (15.6\%) education. Most of the respondents reared cattle $(49.4 \%)$ 
followed by poultry $(28.9 \%)$ and goats $(18.9 \%)$ whilst very few respondents $(2.8 \%)$ reared sheep. The majority of the respondents $(68.3 \%)$ preferred to use a combination of conventional drugs and the least proportion preferred conventional drugs only (10\%). The proportion of respondents that preferred medicinal herbs only (21.7\%) was significantly smaller than those using a combination and significantly greater than those using conventional drugs only $(\mathrm{P}<0.05)$. The conditions that respondents most frequently encountered in livestock were retained placenta (63.9\%) followed by mastitis (57.2\%), wounds (53.9\%), unthriftiness (46.7\%), fractures (26.7\%), arthritis (15\%), constipation (10.6\%) and blindness (3.3\%).

\section{Gender}

Statistical analysis of the results in Table 2 using the $\mathrm{Z}$ test for comparison of proportions showed that the proportion of males using a combination of treatment methods $(79.8 \%)$ was significantly greater than that of the females $(52.7 \%)(\mathrm{P}<0.05)$. The proportion of females using medicinal herbs $(36.8 \%)$ only was significantly greater than that of the males $(10.6 \%)(\mathrm{P}<0.05)$. There was no significant difference in the proportions of males and females using conventional drugs only $(\mathrm{P}>0.05)$.

Table 2. Proportional preference of treatment method according to gender, age and educational level

\begin{tabular}{c|c|c|c|c}
\hline Category & $\begin{array}{c}\text { Conventional } \\
\text { drugs only (\%) }\end{array}$ & $\begin{array}{c}\text { Medicinal } \\
\text { herbs only (\%) }\end{array}$ & $\begin{array}{c}\text { Combination } \\
(\boldsymbol{\%})\end{array}$ & Total (\%) \\
\hline Gender & 9.6 & 10.6 & 79.8 & 100 \\
Male & 10.5 & 36.8 & 52.7 & 100 \\
Female & 37.5 & 12.5 & 50 & 100 \\
\hline Age & 6.7 & 10.2 & 83.1 & 100 \\
<20years old & 2.2 & 32.6 & 65.2 & 100 \\
20-40years old & & & & 100 \\
>40years old & 1.7 & 46.6 & 51.7 & 100 \\
\hline Educational level* & 3.4 & 17.3 & 79.3 & 100 \\
None & 3.2 & 6.3 & 90.5 & 100 \\
Primary & 50 & 7.1 & 42.9 & 100 \\
Secondary & 10 & 21.7 & 68.3 & \\
Tertiary & & & & \\
\hline
\end{tabular}

*The structure of the South Africa education system. Kindergarten is known as 'grade 0' in South Africa, and primary schools are generally divided into junior preparatory schools (grades 0-3) and senior preparatory schools (grades 4-7) before children attend high school (otherwise known as college) from grades 8-12.

https://www.google.com.na/search?q=primary+and+secondary+school+in+south+africa\&rlz=1C1CHZ L_enNA719NA719\&oq=Primary+and+secondary+school+in+South\&aqs $=$ chrome.1.69i57j3315.21755j

$1 \mathrm{j} 7 \&$ sourceid $=$ chrome $\& \mathrm{ie}=\mathrm{UTF}-8$

\section{Age}

Table 2 also showed that a significantly greater proportion of respondents in the 2040 -year-old category $(83.1 \%)$ preferred to use a combination of treatment methods than in the $<20$ years old $(50 \%)$ and the $>40$ years old category $(65.1 \%)(\mathrm{P}<0.05)$. There was no significant difference between the preferred use of a combination of treatment methods between the <20years old and the >40years old categories $(\mathrm{P}>0.05)$. A 
significantly greater proportion of respondents in the >40years old category $(32.6 \%)$ preferred to use medicinal herbs only $(\mathrm{P}<0.05)$. There was no significant difference in the preference of medicinal herbs between the $<20$ years old and the 20-40 years old categories $(\mathrm{P}>0.05)$. A significantly greater proportion of respondents in the $<20$ years old category $(37.5 \%)$ preferred to use conventional drugs only $(\mathrm{P}<0.05)$. A significantly greater proportion of respondents in the $>40$ years old category $(32.6 \%)$ preferred to use medicinal herbs only $(\mathrm{P}<0.05)$.

\section{Educational level}

Table 2 also showed that greater proportions of both primary $(79.3 \%)$ and secondaryschooled respondents $(90.5 \%)$ significantly preferred to use a combination of medicinal herbs and conventional drugs for treatment of their livestock $(\mathrm{P}<0.05)$. There was, however, no significant difference in the proportions of these two groups $(\mathrm{P}>0.05)$. A significantly greater proportion of the unschooled respondents $(46.6 \%)$ preferred to use medicinal herbs only $(\mathrm{P}<0.05)$. There was no significant difference in the proportions of primary $(17.3 \%)$, secondary $(6.3 \%)$ and tertiary-schooled respondents $(7.1 \%)$ that preferred only medicinal herbs as a method of treatment $(\mathrm{P}>0.05)$. A significantly greater proportion of the tertiary-schooled respondents $(50 \%)$ preferred to use conventional drugs only $(\mathrm{P}<0.05)$. There was no significant difference in the proportions of primary $(3.4 \%)$, secondary $(3.2 \%)$ and unschooled respondents $(1.7 \%)$ that preferred only conventional drugs as a method of treatment $(\mathrm{P}>0.05)$.

As shown in Table 3 below, C. abbreviata (stem bark) and C. quadrangularis (branch infusion) were the preferred oral treatments for retained placenta in cattle by the respondents. $P$. angolensis (stem bark) and $C$. collinum (stem bark) were the preferred oral treatments for constipation in cattle by the respondents. A. crytopoda (leaf infusion) was the only preferred oral treatment of unthriftness in poultry. The rest of the plants were used topically for treatment of wounds in cattle, sheep and goats $(C$. quadrangularis, D. cinerea and $X$. Americana), arthritis ( $S$. cupulare), mastitis ( $Z$. mucronata), fractures (M. eduncularis) and blindness ( $G$. herbaceum) in cattle, sheep and goats.

\section{Discussion}

This study has shed some light on the dynamics of use of EVM in Mutale municipality of Vhembe district of South Africa. The study showed that EVM is used more by the older (more than 40 years old) members of the community (49\%) than by younger generation (Table 1). These results are in agreement with several previous workers who reported that knowledge of medicinal plants use is mostly limited to older people in the communities (Shen et al., 2010; Bartha et al., 2015; Nyahangare et al., 2015; Ahmad et al., 2016; Usha et al., 2016). According to Bartha et al. (2015), the older members of the population have a tendency to choose EVM over allopathic veterinary medicine. This scenario where the aged population is the custodian of EVM and vanguard of its use presents a real risk of permanent loss of this treasure of knowledge that has been gathered over generations. Ahmad et al. (2016) contends that vesting the EVM in older members of the community is vulnerable to and may be undermined by mortality. Consequently, urgent documentation of EVM in rural communities such as Mutale is required so as to conserve such knowledge before this biocultural heritage disappears altogether. 
Table 3. Plants and plant parts used by respondents for treatment of livestock conditions

\begin{tabular}{|c|c|c|c|c|}
\hline Botanical name & $\begin{array}{c}\text { English/local } \\
\text { name }\end{array}$ & Indications & $\begin{array}{c}\text { Preparation } \\
\text { used }\end{array}$ & $\begin{array}{c}\text { Route of } \\
\text { administration }\end{array}$ \\
\hline $\begin{array}{l}\text { Caesalpiniaceae } \\
\text { Cassia abbreviate }\end{array}$ & $\begin{array}{l}\text { Long pod cassia } \\
\text { Muboma }\end{array}$ & $\begin{array}{l}\text { Retained placenta in } \\
\text { cattle }\end{array}$ & $\begin{array}{l}\text { Stem bark } \\
\text { infusion }\end{array}$ & Oral \\
\hline $\begin{array}{c}\text { Vitaceae } \\
\text { Cissus } \\
\text { quadrangularis }\end{array}$ & $\begin{array}{l}\text { Devil's backbone } \\
\text { Malongakanya }\end{array}$ & $\begin{array}{c}\text { Retained placenta in } \\
\text { cattle } \\
\text { Wounds in cattle }\end{array}$ & $\begin{array}{l}\text { Branch } \\
\text { infusion } \\
\text { Branch } \\
\text { infusion }\end{array}$ & $\begin{array}{c}\text { Oral } \\
\text { Topical }\end{array}$ \\
\hline $\begin{array}{l}\text { Asphodelaceae } \\
\text { Aloe cryptopoda }\end{array}$ & $\begin{array}{l}\text { Dr Kirk's aloe } \\
\text { Tshikhopha }\end{array}$ & $\begin{array}{l}\text { Unthriftiness in } \\
\text { poultry }\end{array}$ & $\begin{array}{l}\text { Leaf } \\
\text { infusion }\end{array}$ & Oral \\
\hline $\begin{array}{c}\text { Fabaceae } \\
\text { Pterocarpus } \\
\text { angolensis }\end{array}$ & $\begin{array}{c}\text { Bloodwoood/wild } \\
\text { teak } \\
\text { Mutondo }\end{array}$ & Constipation in cattle & $\begin{array}{l}\text { Stem bark } \\
\text { infusion }\end{array}$ & Oral \\
\hline $\begin{array}{l}\text { Euphorbiaceae } \\
\text { Synadenium } \\
\text { cupulare }\end{array}$ & $\begin{array}{l}\text { Dead-man's tree } \\
\text { Muswoswo }\end{array}$ & $\begin{array}{l}\text { Arthritis in cattle, } \\
\text { sheep and goats }\end{array}$ & Resin & Topical \\
\hline $\begin{array}{c}\text { Combretaceae } \\
\text { Combretum } \\
\text { collinum }\end{array}$ & $\begin{array}{l}\text { Bicoloured } \\
\text { bushwillow } \\
\text { Muvuvha }\end{array}$ & Constipation in cattle & Stem Bark & Oral \\
\hline $\begin{array}{c}\text { Olacaceae } \\
\text { Ximenia americana }\end{array}$ & $\begin{array}{c}\text { Tallow } \\
\text { wood/Sour plum } \\
\text { Muthanzwa }\end{array}$ & $\begin{array}{l}\text { Wounds in cattle sheep } \\
\text { and goats }\end{array}$ & $\begin{array}{l}\text { Root bark } \\
\text { powder }\end{array}$ & Topical \\
\hline $\begin{array}{l}\text { Celastraceae } \\
\text { Maytenus } \\
\text { eduncularis }\end{array}$ & $\begin{array}{c}\text { Silkybarks } \\
\text { Mukwatukwatu }\end{array}$ & Fractures in cattle & $\begin{array}{l}\text { Root bark } \\
\text { paste }\end{array}$ & Topical \\
\hline $\begin{array}{l}\text { Mimosaceae } \\
\text { Dichrostachys } \\
\text { cinerea }\end{array}$ & $\begin{array}{l}\text { Sicklebush/ } \\
\text { Kalahari } \\
\text { Christmas tree } \\
\text { Murenzhe }\end{array}$ & $\begin{array}{l}\text { Wounds in sheep and } \\
\text { goats }\end{array}$ & $\begin{array}{l}\text { Fried fruit } \\
\text { powder }\end{array}$ & Topical \\
\hline $\begin{array}{c}\text { Rhamnaceae } \\
\text { Ziziphus mucronata }\end{array}$ & $\begin{array}{l}\text { Buffalo thorn tree } \\
\text { Mutshetshete }\end{array}$ & Mastitis in cattle & Leaf paste & Topical \\
\hline $\begin{array}{l}\text { Malvaceae } \\
\text { Gossypium } \\
\text { herbaceum }\end{array}$ & $\begin{array}{l}\text { Levant cotton } \\
\text { Muluvha }\end{array}$ & $\begin{array}{l}\text { Blindness in cattle, } \\
\text { sheep and goats }\end{array}$ & Seed powder & Topical \\
\hline
\end{tabular}

According to our results, more males (57.8\%) than females $(42.2 \%)$ responded to our questionnaire. The majority of them reared cattle compared to other livestock species (Table 1). In spite of there being more male that female respondents, the results show that EVM is made use of mainly by females (Table 2) in the more than 40-year age group (Table 3). These findings are similar to those reported by Mwale and Masika (2009) in the Eastern Cape and Luseba and Van der Merwe (2006) in Limpopo Province of South Africa. Elsewhere in Ethiopia, Teklehaymanot (2017) reported that more males than females were involved in EVM. Similarly, Taliq et al. (2014) reported that, in the Kohat region of Pakistan, women and younger generations were not 
involved in the use of EVM. Taliq et al. (2014) reported that men had better knowledge regarding ethno veterinary practices as compared to women. The reason advanced for this observation was that men are mostly favoured in shift of knowledge while women in the majority of the cultures are relegated to family care. The noticeable gender bias observed in our study suggests limited involvement of men in cattle production and herd health in the Mutale local municipality.

The study also shows that EMV is embraced more by the members of the society with no education (46.6\%) or with primary education (17.3\%) (Table 4). This scenario is not sustainable, and the literate section of the society must begin to embrace and document the use of such practices. The fact that the majority $(78.3 \%)$ of the farmers use EVM in one way or another (conventional and allopathic veterinary medicine $68.3 \%$ and EVM alone $10 \%$ ) is encouraging. This means that only $21 \%$ of the farmers in Mutale municipality have not yet adopted the use of EVM. Use of a combination of EVM and allopathic medicine is not unique to South Africa and has been reported elsewhere (Claudell et al., 2017). However, it is not clear from our results if the trend towards adoption of EVM is increasing or decreasing. Given that in South Africa, as in other African countries, many veterinarians and decision makers have not critically examined and incorporated the potential of EVM into primary animal healthcare, the future of EVM appears to be bleak. The fact that EVM has not yet been incorporated into technical and undergraduate veterinary training curricula does not bode well for the future of this practise either. Empirical evidence suggests that many in positions of veterinary authority tend to ignore or ridicule EVM paints a gloomy picture on the adoption of EVM in South Africa. There is need for the documentation, validation and incorporation of EVM in primary animal healthcare in South Africa to the benefit of future generations. Enhancement of this approach is most likely to spur research and development of EVM and undoubtedly enable it to make immense strides in the development of the livestock industry.

Rural farmers rely economically on small scale livestock production which may be complemented by seasonal crop production. Particularly in tropical areas, animal husbandry plays a key role in rural economies as a source of cash income and employment (Herrero et al., 2013). In rural communities where livestock theft is a challenge, farmers keep their livestock in the kraals at night and provide them access to grazing during daylight hours, thus, keeping themselves updated on their livestock's health status. When abnormal health conditions are identified, farmers with little or no access to the modern veterinary services resort to indigenous methods of treating identified diseases. Results of the present study complement the previous findings that wild fodder plants and traditional EVM practices based on medicinal plants can help local communities to cope with environmental and socioeconomic disturbances within livestock systems. As pointed out by several studies (Gómez-Baggethum et al., 2012), transmission of this biocultural heritage is at the base of human adaptive strategies and can play a critical role in minimizing the impact of disturbances on livelihood of local communities, especially those living in highly unpredictable systems like Mopane woodlands. On the other hand, these biological resources could be expected to play an increasingly critical role in securing feed and health for livestock in the near future. Furthermore, results from the present study supported the view that initiatives to conserve indigenous knowledge is paramount as loss of this vital knowledge system affects rural communities (Dwebaa and Mearns, 2011). Recognizing problems at community level is an essential step for supporting any interventional activities 
(Ravikumar et al., 2016). Local communities need to be in forefront towards knowledge creation, distribution and sharing system (Lwoga et al., 2010). Creative expressions of informal society can provide solutions and accessibility to appropriate technology (Kumar et al., 2013).

Previous research results revealed several plants that can be used reliably and safely to treat livestock. Legal registration of these botanical products is usually not required for their promotion. This approach offers sustainable strategies directed towards developing sound and appropriate animal health care systems suitable and relevant to rural communities in improving livestock performance and production and, hence, livelihood (Stevenson et al., 2010). The current study identified nine livestock conditions which were treated by 11 plants belonging to 10 families. Among the livestock conditions reported mastitis, retained placenta and wounds were frequently mentioned to occur in cattle. These livestock conditions were similar to the ones reported elsewhere in literature and treated by the use of medicinal plants (Dilshad et al., 2010; Gebrezgabiher et al., 2013; Luseba and Tshisikhawe, 2013). Retained placenta was found to be most common in domestic animals and two plant families were used against this condition (Table 1). This contradicts with Taliq et al. (2014) who reported gastrointestinal infections to be most common in domestic animals. Similar to previous studies, farmers in Mutale municipality reported that they were able to define diseases using clinical signs. However, the use of clinical signs only for diagnosis of diseases is not effective as it reduces the accuracy of the diagnosis thereby resulting in incorrect dosages and reduced effectiveness of herbal remedies.

Although livestock conditions in this study are similar to the ones reported previously, different medicinal plants, methods of preparation and to a certain extent administering methods were used. Lack of knowledge or prior experience with alternative therapies can influence willingness of farmers to use plants in treatment of ailments (Richert et al., 2013). Furthermore, different production systems influence decision by farmers to implement disease control strategies (Jemberu et al., 2015). Fabaceae family was only mentioned for the treatment of constipation in cattle. This observation is different from that of Appidi et al. (2008) who in an ethno veterinary survey reported Fabaceae family as the most commonly used plant by livestock farmers. Luseba and Tshisikhawe (2013) reported the use of Bolusanthus speciosus (Fabaceae) as a remedy for retained placenta when orally supplied in cattle after crushing and immersing the roots in water for $12 \mathrm{~h}$. In this study when retained placenta was identified two plants (Cassia abbreviata and Cissus quadrangularis) from two different families (Caesalpiniaceae and Vitaceae) were used respectively. The bark of Cassia abbreviata when crushed and infused in water for more than 30 minutes (or less if shaking is done to facilitate quicker extraction of the chemicals) was reportedly used for treatment of retained placenta in the current study. The solution was reported to be administered orally until the complete discharge of placental membranes (Table 2). The difference among studies might be related to the differences in the dominant vegetation of the areas or might be associated with traditional beliefs of different cultures in traditional use of specific plants. Plants from the Asteraceae family were reportedly popular among traditional healers in Pakistan for the preparation of traditional medicines used in treatment of different livestock and human ailments (Khan et al., 2014; Akhtar et al., 2013). The fleshy branches of Cissus quadrangularis were crushed and infused in water; the solution was then used to clean the wound area. These results are in line with the findings of Gebrezgabiher et al. (2013) who reported that wound 
treatment was done by topical application of the medication. Previous studies reported that Cissus quadrangularis exhibits strong antioxidant and free radical scavenging ability due to the presence of $\beta$-carotene (Mallik and Shymala Devi, 2005).

A high tannin-containing plant species Ziziphus mucronata was frequently mentioned by the respondents for treating mastitis in cattle. These results are in agreement with the findings of Dilshad et al. (2010) who reported the use of tannin containing plants for treating mastitis in dairy cows. Combcv xbretum collium was used in ruminants as a remedy to relieve constipation. According to Edwards et al. (1995), leaves and bark of Combretum collium are widely used in local medicine to treat various intestinal disorders including diarrhea, colic and jaundice. Interestingly, in the present study the bark of the same plant species was reportedly used for treating constipation. Pterocarpus angolensis, well known for its high tannin content, was also mentioned with respect to constipation (Luseba et al., 2007). Tannins occur naturally in plants and have been reported to have a wide range of medicinal uses due to their antiinflammatory, anti-fungal, mucoprotectant, antioxidant, enzyme inhibition and antibacterial properties (McGaw et al., 2007). Swollen joints were reportedly treated by topical application of the latex-like sap from the branches of Synadenium cupulare. The roots of this plant have been reported to possess medicinal properties (Chauke et al., 2015). Respondents reported the use of Aloe species for treating poultry conditions. The findings are similar to those from previous studies where Aloe species were commonly used for treating poultry diseases including Newcastle disease (Mwale et al., 2005; Adedeji et al., 2013). Patterns in the ethnographic literature indicate that widespread, common Aloe species in Southern Africa are more likely to be popular, multi-use ethno medicines than rare species with narrow ranges (Glen and Hardy, 2006). Aerial parts of the plants were frequently reportedly used instead of beneath ground parts (Table 5). These results are in line with those of Ul Hassan et al. (2014); Luseba and Tshisikhawe (2013) who reported the frequent use of aerial plant parts containing medicinal properties in a plant instead of parts beneath the ground.

The present results are in agreement with other studies where roots were also used in ethno veterinary practices (Cheikhyoussef et al., 2011). However, the use of roots in preparation of herbal remedies is not advisable, as this results in loss of plants from their natural habitats. In the present study, leaves were only mentioned for the family Rhamnaceae (Table 3) in contradiction with previous findings which reported a more frequent use of leaves followed by whole plant (Tariq et al., 2014; Gebrezgabiher et al., 2013; Maphosa and Masika, 2010; Setlalekgomo and Setlalekgomo, 2013; Bhatt, 2013). The use of leaves in preparation of herbal remedies is considered a sustainable type of harvesting as it reduces loss of plants from the natural habitats. Farmers in Mutale municipality ought to use aerial plant parts such as leaves rather than the whole plant or roots to prevent plants from becoming extinct (Maroyi, 2012). Furthermore, leaves are the main site of the photosynthetic apparatus and are involved in a variety of physiological processes of plants and produce numerous secondary metabolites that could be a possible reason for their effectiveness and efficacy against different livestock diseases (Bhatt, 2013).

In the current study, few plants possessed medicinal properties in their fruits. Hassan et al. (2013) reported the use of a whole plant for medicinal purposes. In our study there was no case where respondents cited the use of a whole plant for medicinal purposes. This is a good indication since the use of whole plants could lead to a very destructive type of harvesting especially for rare and slow-growing plants from a conservation point 
of view (Tariq et al., 2014). Furthermore, a majority of the medicinal plants cited in this study were not cultivated by the respondents. However, one farmer reported to have planted a shrub (Synadenium cupulare) specifically for medicinal purposes. A study conducted in Pakistan by Dilshad et al. (2010), reported the use of cultivated plants (Oryza sativa and Triticum aestivum) for treating mastitis in dairy cows. A majority of the Mutale farmers interviewed collected the medicinal herbs from their natural habitats. This is a good indication since it is advisable to use wild plants that grow under stress conditions and competition, as they possess secondary metabolites which improve their medicinal properties (Schippmann et al., 2003). In addition, banana roots (Musa paradisiacal) were reported to treat internal parasites (worms) in animals when crushed and administered orally after infusion in water. Most plant parts were crushed and infused in water to influence easier extraction of the chemicals within. The methods of application used by local farmers in the current study did not differ from the methods reported by Sindhu et al. (2010) among Pakistan local farmers. Crushing of plant parts and mixing with water were common when medication was administered orally. This is in agreement with Maphosa and Masika (2010) and (Djoueche et al., 2011). Deeba (2009) indicated that powdering or boiling is the most common method of drugs extraction. These findings are in line with a study conducted in the Malakand valley of Pakistan (Ul Hassan et al., 2014). The difference in application methods are in agreement with the findings of McCorkle and Mathias-Mundy (1992) who reported that the mode of preparation of the medication depends on active ingredient to be extracted, and the method of administration.

Oral and topical routes were the only mentioned routes of administration in the present study. This agrees with the findings from previous studies (Tariq et al., 2014). Similar to what was reported in other studies, the ethno veterinary practices of livestock farmers in Mutale municipality are not extensively documented and are mostly passed orally from elders (Farooq et al., 2009). It is important to document ethno-veterinary knowledge so that it will not be lost and to increase the use of common plants.

\section{Conclusion}

The present study revealed that EVM is an important part of the livelihood of local farmers residing in the Mutale local municipality. The concept of EVM is highly appreciated and embraced mostly by old farmers who indicated to have acquired the knowledge from their elders' earlier. At present the transfer of this valuable knowledge to younger generations is a challenge considering the substantial development and education system limited to modernized drugs. EVM should not be neglected since it is the only hope for resource limited livestock farmers. However, further studies are still needed to educate farmers on sustainable utilization of indigenous natural resources and evaluation of the chemical composition of medicinal plants reported in this study. Gaining knowledge on the chemical composition of medicinal plants may be beneficial in drug development. It is expected that the situation regarding the use of plants to treat livestock in Mutale Municipality has most probably remained the same or, better still, improved.

Acknowledgements. The authors wish to express their gratitude to the livestock farmers of Mutale local municipality for their cooperation and University of Limpopo's Department of Agricultural Economics and Animal Production for allowing us to carry out this study. 
Author contributions. Teedzai Chitura contributed to the supervision, funding acquisition and execution of the study, writing and editing of the final manuscript. Borden Mushonga contributed to the project planning, implementation, writing of the original draft and editing the final manuscript. Pfunzo Tonny Muvhali contributed to the study design and investigation. Erick Kandiwa contributed to planning, implementation, data curation, writing and editing of the manuscript. Kamogelo Shai contributed to the review and editing of the manuscript.

\section{REFERENCES}

[1] Adamu, M., Naidoo, V., Eloff, J. N. (2014): The antibacterial activity, antioxidant activity and selectivity index of leaf extracts of thirteen South African tree species used in ethnoveterinary medicine to treat helminth infections. - BMC Veterinary Research 10(1): 52.

[2] Adedeji, O. S., Ogunsina, T. K., Akinwumi, A. O., Ameen, S. A., Ojebiyi, O. O., Akinlade, J. A. (2013): Ethno veterinary medicine in African organic poultry production. - International Food Research Journal 20: 527-532.

[3] Ahmad, S., Gangoo, S. A., Sultan, S. M., Dar, M. D. (2016): Ethnoveterinary practices and use of herbal medicine by pastoralists of Himalaya: a review. - Annals of Biology 32(2): 260-268.

[4] Akhtar, N., Rashid, A., Murad, W., Bergmeier, E. (2013): Diversity and use of ethnomedicinal plants in the region of Swat, North Pakistan. - Journal of Ethnobiology and Ethnomedicine 9: 9-25.

[5] Appidi, J. R., Grierson, D. S., Afolayan, A. J. (2008): Ethnobotanical study of plants used for the treatment of diarrhoea in the Eastern Cape, South Africa. - Pakistan Journal of Biological Sciences 11(15): 1961-1963.

[6] Bartha, S. G., Quave, C. L., Balogh, L., Papp, N. (2015): Ethnoveterinary practices of Covasna County, Transylvania, Romania. - Journal of Ethnobiology and Ethnomedicine 11(1): 35 .

[7] Bhatt, A., Singh, P., Kumar, V., Baunthiya, M. (2013): Documentation of ethno veterinary practices used for treatments of different ailments in Garhwal Himalayan Region. - Journal of Environmental Nanotechnology 2: 22-29.

[8] Caudell, M. A., Quinlan, M. B., Quinlan, R. J., Call, D. R. (2017): Medical pluralism and livestock health: ethnomedical and biomedical veterinary knowledge among East African agropastoralists. - Journal of Ethnobiology and Ethnomedicine 13(1): 7.

[9] Chauke, M. A., Shai, L. J., Mogale, M. A., Tshisikhawe, M. P., Mokgotho, M. P. (2015): Medicinal plant use of villagers in the Mopani district, Limpopo Province, South Africa. - African Journal of Traditional, Complementary and Alternative Medicines 12: 9-26.

[10] Cheikhyoussef, A., Shapi, M., Matengu, K., Ashekele, H. M. (2011): Ethnobotanical study of indigenous knowledge on medicinal plant use by traditional healers in Oshikoto region, Namibia. - Journal of Ethnobiology and Ethnomedicine 7(10): 1-11.

[11] Chinsembu, K. C., Negumbo, J., Likando, M., Mbangu, A. (2014): An ethnobotanical study of medicinal plants used to treat livestock diseases in Onayena and Katima Mulilo, Namibia. - South African Journal of Botany 94: 101-107.

[12] Deeba, F. (2009): Documentation of ethno veterinary practices in urban and periurban areas of Faisalabad, Pakistan. - PhD Thesis, University of Agriculture, Faisalabad Pakistan.

[13] Dilshad, S. M. R., Rehman, N. U., Ahmad, N., Iqbal, A. (2010): Documentation of ethnoveterinary practices for mastitis in dairy animals in Pakistan. - Pakistan Veterinary Journal 30: 167-171.

[14] Djoueche, C. M., Azebaze, A. B., Dongmo, A. B. (2011): Investigation of plants used for the ethno veterinary control of gastro-intestinal parasites in Benoue Region, Cameroon. Tropicultura 29(4): 205-211. 
[15] Doumbia, D., Van Paassen, A., Oosting, S. J., Van der Zijpp, A. J. (2012): Livestock in the rice based economy of Office du Niger: The development potential for increased croplivestock integration through multi-actor processes. - Wageningen Journal of Life Sciences 60(63): 101-114.

[16] Dwebaa, T. P., Mearns, M. A. (2011): Conserving indigenous knowledge as the key to the current and future use of traditional vegetables. - International Journal of Information Management 31(6): 564-571.

[17] Edwards, S., Tadesse, M., Hedberg, I. (1995): Flora of Ethiopia and Eritrea, Volume 2, Part 2. Canellaceae to Euphorbiaceae. Review by: Mike Lock. - Royal Botanic Garden Kew 53: 758-760.

[18] Farooq, M., Wahid, A., Kobayash, N., Fujita, D., Basra, S. M. A. (2009): Plant drought stress: effects, mechanisms and management. - Agronomy for Sustainable Development 29(1): 185-212.

[19] Gabanakgosi, K., Moreki, J. C., Nsoso, S. J., Tsopito, C. (2012): Ethnoveterinary medicine usage in family chickens in the selected four villages of Botswana. - Journal of Veterinary Advances 2(12): 586-594.

[20] Gebrezgabiher, G., Kalayou, S., Sahle, S. (2013): An ethno-veterinary survey of medicinal plants in Woredas of Tigray region, Northern Ethiopia. - Internal Journal of Biodiversity and Conservation 5: 89-97.

[21] Getachew, T., Kebede, E., Ameha, N., Terefe, T. A. (2015): Village chicken husbandry practice, marketing and constraints in Eastern Ethiopia. - Journal of Animal and Poultry Sciences 5(4): 104-108.

[22] Glen, H. F., Hardy, D. S. (2006): Aloaceae (First part): Aloe. - In: Germishuizen, G. (ed.) Flora of Southern Africa. 5, Fascicle. National Botanical Institute, South Africa.

[23] Gómez-Baggethum, E., Reyes-Gacia, V., Olson, P., Montes, C. (2012): Traditional ecological knowledge and community resilience to environmental extremes: A case study in Doñana, SW Spain. - Global Environmental Change 22(3): 640-650.

[24] Hassan, S. H. A., Fry, J. R., AbuBakar, M. F. (2013): Phytochemicals content, antioxidant activity and acetylcholinesterase inhibition properties of indigenous Garcinia parvifolia fruit. - Biomedical Research International 7: 201.

[25] Herrero, M., Grace, D., Njuki, J., Johnson, N., Enahoro, D., Silvestri, S., Rufino, M. C. (2013): The roles of livestock in developing countries. - Animal 7: 3-18.

[26] Jemberu, W. T., Mourits, M. C. M., Hogeveen, H. (2015): Farmers' intentions to implement foot and mouth disease control measures in Ethiopia. - PLoS One. 10(9): e0138363. http:// dx.doi.org/10.1371/journal.pone.0138363.

[27] Khan, I., AbdElsalam, N. M., Fouad, H. et al. (2014): Application of ethnobotanical indices on the use of traditional medicines against common diseases. - Evidence Based Complementary and Alternative Medicine. http://dx.doi.org/10.1155/2014/635371.

[28] Kumar, V., Chand, V. S., Zhang, L., Hoppers, C. A. O., Zhang, W., Esders, M., Gupta, A. K. (2013): Grassroots innovations for inclusive development: need for a paradigmatic shift. - Vikalpa 38(3): 103-122.

[29] Lans, C., Bevan, J., Turner, N. (2012): Plants used in rearing locally-grown organic small-scale poultry and rabbits in British Columbia, Canada. - Current Nutrition and Food Science 8(3): 220-234.

[30] Luseba, D., Tshisikhawe, M. P. (2013): Medicinal plants used in the treatment of livestock disease in Vhembe region, Limpopo Province, South Africa. - Journal of Medicinal Plant Research 7: 593-601.

[31] Luseba, D., Van der Merwe, D. (2006): Ethnoveterinary medicine practices among Tsonga speaking people of South Africa. - Onderstepoort Journal of Veterinary Research 73: 115-122.

[32] Luseba, D., Elgorashi, E. E., Ntloedibe, D. T., Staden, J. V. (2007): Antibacterial, antiinflammatory and mutagenic effects of some herbal plants used in South Africa for the 
treatment of wounds and retained placenta in livestock. - South African Journal of Botany 73: 378-383.

[33] Lwoga, E. T., Ngulube, P., Stilwell, C. (2010): Understanding indigenous knowledge: Bridging the knowledge gap through a knowledge creation model for agricultural development. - South African Journal of Information Management 12(1): 436.

[34] Makhado, R. A., Potgieter, M. J., Wessels, D. C. J., Saidi, A. T., Masehela, K. L. (2012): Use of Mopane woodland resources and associated woodland management challenges in rural areas of South Africa. - Journal of Applied Ethnobotanical Research 10: 369-380.

[35] Makhado, R. A., Potgieter, M. J., Timberlake, J., Gumbo, D. (2014): A review of the significance of Mopane products to rural people's livelihoods in Southern Africa. Trans. Royal Soc. South Africa 69(2): 117-122.

[36] Mallik, J., Shyamala Devi, C. S. (2005): In vitro and in vivo evaluation of free radical scavenging potential of Cissus quadrangularis. - African Journal of Biomedical Research 8: 95-99.

[37] Mamidala, E. (2013): Ethnobotanical survey in different mandals of Adilabad district, Andhra Pradesh, India. - International Journal of Science 2: 77-83.

[38] Maphosa, V., Masika, P. J. (2010): Ethnoveterinary uses of medicinal plants: A survey of plants used in the ethnoveterinary control of gastrointestinal parasites of goats in the Eastern Cape Province, South Africa. - Pharmaceutical Biology 48(6): 697-702.

[39] Maphosa, V., Tshisikhawe, M. P., Thembo, K., Masika, P. J. (2010): Ethnoveterinary Medicine in Southern Africa. - In: Katerere, D. R., Luseba, D. (eds.) Ethnoveterinary Botanical Medicine Herbal Medicines for Animal Health. CRC Press, Boca Raton.

[40] Marandure, T. (2016): Concepts and key issues of ethnoveterinary medicine in Africa: A review of its application in Zimbabwe. - African Journal of Agricultural Research 11(20): 1836-1841.

[41] Maroyi, A. (2012): Use of traditional veterinary medicine in Nhema communal area of the Midlands Province, Zimbabwe. - African Journal of Traditional, Complementary and Alternative Medicines 9(3): 315-322.

[42] Mayer, M., Vogl, C. R., Amorena, M., Hamburger, M., Walkenhorst, M. (2014): Treatment of organic livestock with medicinal plants: a systematic review of European ethnoveterinary research. - Complementary Medicine Research 21(6): 375-386.

[43] McCorkle, C. M., Mathias-Mundy, E. (1992): Ethno veterinary medicine in Africa. Journal of International African Institute 62: 59-93.

[44] McGaw, L. J., Eloff, J. N. (2008): Ethnoveterinary use of southern African plants and scientific evaluation of their medicinal properties. - Journal of Ethnopharmacology 119(3): 559-574.

[45] McGaw, L. J., Van der Merwe, D., Eloff, J. N. (2007): In vitro anthelmintic, antibacterial and cytotoxic effects of extracts from plants used in South African ethno veterinary medicine. - Veterinary Journal 173: 366-372.

[46] Moyo, B., Masika, P. J., Dube, S., Maphosa, V. (2009): An in-vivo study of the efficacy and safety of ethnoveterinary remedies used to control cattle ticks by rural farmers in the Eastern Cape Province of South Africa. - Tropical Animal Health and Production 41: 1569-1576.

[47] Moyo, B., Ndlovu, L., Moyo, S., Masika, P. J., Muchenje, V., Ndhlovu, D. N., Maphosa, V. (2013): Alternative remedies and approaches used by resource challenged farmers in the management of black leg disease in cattle in Umzingwane district of Matebeleland South. - Internal Journal of Livestock Production 6: 77-102.

[48] Mucina, L., Rutherford, M. C. (2006): The Vegetation of South Africa, Lesotho and Swaziland. Strelitzia 19. - South African National Biodiversity Institute, Pretoria.

[49] Munda, S., Pandey, R., Bhojne, G. R., Dakshinkar, N., Kinhekar, A. S., Kumar, V., Ravikumar, R. K., Kumar, V. (2016): Indigenous Knowledge Research System (IKRS) for treatment of bloat and its significance towards greenhouse gas emission: Jharkhand, India. - Advances in Animal and Veterinary Sciences 4(5): 241-249. 
[50] Mutibvu, T., Maburutse, B. E., Mbiriri, D. T., Kashangura, M. T. (2012): Constraints and opportunities for increased livestock production in communal areas: A case study of Simbe, Zimbabwe. - Livestock Research and Rural Development 24: 9.

[51] Mwale, M., Masika, P. J. (2009): Ethnoveterinary control of parasites, management and role of village chickens in rural households of Centane district in the Eastern Cape, South Africa. - Tropical Animal Health and Production 41(8): 1685-1693.

[52] Mwale, M., Bhebhe, E., Chimoyo, M., Halimani, T. E. (2005): Use of herbal plants in poultry health management in the Mushagashe small-scale commercial farming area in Zimbabwe. - International Journal of Applied Research in Veterinary Medicine 3: 163170.

[53] Ndhlala, A. R., Amoo, S. O., Stafford, G. I., Finnie, J. F., Van Staden, J. (2009): Antimicrobial, anti-inflammatory and mutagenic investigation of the South African tree aloe (Aloe barberae). - Journal of Ethnopharmacology 124(3): 404-408.

[54] Notenbaert, A., Pfeifer, C., Silvestri, S., Herrero, M. (2017): Targeting, out-scaling and prioritising climate-smart interventions in agricultural systems: Lessons from applying a generic framework to the livestock sector in sub-Saharan Africa. - Agricultural Systems 151: 153-162.

[55] Nyahangare, E. T., Mvumi, B. M., Mutibvu, T. (2015): Ethno veterinary plants and practices used for ecto parasites control in semi-arid small holder farming areas of Zimbabwe. - Journal of Ethnobiology and Ethno Medicine 11: 30.

[56] Paindla, P., Vijayagiri, R. C., Mamid, E. (2013): Ethno survey in different madals of Adilabad District, Andhra Pradesh, India. - International Journal of Science 2: 77-83.

[57] Raikwar, A., Maurya, P. - (2015): Ethnoveterinary medicine: in present perspective. International Journal of Agricultural Sciences and Veterinary Medicine 3(1): 44-49.

[58] Raot, U. S., Parmar, M., Patel, P., Patel, R., Gogoi, D. M., Patel, J., Sivapregasam, V., Kumar, V., Ravikumar, R. K., Kumar, V. (2016): Value addition of novel herbal livestock medication Mastiherb in treatment of mastitis sustained by creative communities from the regions of Dang, Gujarat. - International Journal of Bio-resource and Stress Management 7(3): 501-507.

[59] Ravikumar, R. K., Dutta, L., Kinhekar, A. S., Kumar, V. (2016): People's knowledge for addressing societal needs: Lessons learnt while engaging farming communities as a part of research system. - Advances in Animal and Veterinary Sciences 4(1): 1-8.

[60] Richert, R. M., Cicconi, K. M., Gamroth, M. J., Schukken, Y. H., Stiglbauer, K. E., Ruegg, P. L. (2013): Risk factors for clinical mastitis, ketosis, and pneumonia in dairy cattle on organic and small conventional farms in the United States. - Journal of Dairy Science 96: 1-17.

[61] Ritter, R. A., Monteiro, M. V. B., Monteiro, F. O. B., Rodrigues, S. T., Soares, M. L., Silva, J. C. R., Palha, M. D. C., Biondi, G. F., Rahal, S. C.,. Tourinho, M. M. (2012): Ethnoveterinary knowledge and practices at Colaresisland, Para State, eastern Amazon, Brazil. - Brazilian Journal of Pharmacognosy 144: 346-352.

[62] S. A. Explorer (2014): Mutale climate. - http://www.saexplorer.co.za/southafrica/climate/mutale_climate.asp (accessed on 23 April 2014).

[63] Setlalekgomo, M., Setlalekgomo, T. (2013): The use of ethnoveterinary medicine in goats in Lentsweletau Village in Kweneng District of Botswana. - Journal of Veterinary Advances 7: 197-202.

[64] Shamim, A., Hassan, M. U., Yousaf, A., Iqbal, M. F., Zafar, M. A., Siddique, R. M., Abubakar, M. (2015): Occurrence and identification of Emeria species in broiler rearing under traditional system. - Journal of Agricultural Science and Technology 57: 41.

[65] Shen, S., Qian, J., Ren, J. (2010): Ethnoveterinary plant remedies used by Nu people in NW Yunnan of China. - Journal of Ethnobiology and Ethnomedicine 6(1): 24.

[66] Sindhu, Z., Iqbal, Z., Khan, M. N., Jonsson, N. N., Siddique, M. (2010): Documentation of ethnoveterinary practices used for treatment of different ailments in a selected hilly area of Pakistan. - International Journal of Agriculture and Biology 12: 353-358. 
[67] Sserunkuma, P., McGaw, L. J., Nsahlai, I. V., Van Staden, J. (2017): Selected southern African medicinal plants with low cytotoxicity and good activity against bovine mastitis pathogens. - South African Journal of Botany 111: 242-247.

[68] Stevenson, P., Simmonds, M., Belmain, S. (2010): Caesalpinioid Woodlands of Southern Africa: Optimising the Use of Pesticidal Plants. Chatham: Southern African Pesticidal Plants (SAPP) Project. Final Technical Report. - Natural Resources Institute, University of Greenwich.

[69] Tariq, A., Hassan, U. H., Murad, W. et al. (2014): Ethnoveterinary study of medicinal plants in Malakand Valley, District Dir (Lower), Khyber Pakhtunkhwa, Pakistan. - Irish Veterinary Journal 67: 6.

[70] Teklehaymanot, T. (2017): An ethnobotanical survey of medicinal and edible plants of Yalo Woreda in Afar regional state, Ethiopia. - Journal of Ethnobiology and Ethno Medicine 13(1): 40.

[71] Tyasi, T. L., Nkohla, M. B. (2015): In-vivo validation of the Elephantorrhiza elephantina's efficacy as alternative in the control of coccidia infections in goats. African Journal of Environmental Sciences and Technology 3: 225-229.

[72] Ul Hassan, H., Murad, W., Akash Tariq, A., Ahmad, A. (2014): Ethnoveterinary study of medicinal plants in Malakand Valley, District Dir (Lower), Khyber Pakhtunkhwa, Pakistan. - Irish Veterinary Journal 67: 1-6.

[73] Usha, S., Rajasekaran, C., Siva, R. (2016): Ethnoveterinary medicine of the Shervaroy Hills of Eastern Ghats, India as alternative medicine for animals. - Journal of Traditional and Complementary Medicine 6(1): 118-125.

[74] Vijayagiri, R. C., Mamidala, E. (2012): Ethnobotanical investigations among traditional healers in Warangal district of Andhra Pradesh, India. - Pharmacognosy Journal 4(34): 13-17. 